Vol. 4 No.2 Juni 2021

http://jurnal.umsb.ac.id/index.php/RANGTEKNIKJOURNAL

\title{
Sistem Informasi Akademik Pada SMA N 1 Palembayan Berbasis Web Menggunakan Framework Bootstrap
}

\author{
Nelfira $^{1}$, Amuharnis ${ }^{2}$, Elizamiharti ${ }^{3}$, Cindy Wiriani ${ }^{4}$ \\ Sistem Informasi, STMIK Indonesia Padang ${ }^{1,2,3,4}$ \\ Email: nelfira@stmikindonesia.ac.id ${ }^{1}$, amuharnis@stmikindonesia.ac.id ${ }^{2}$, \\ elizamiharti2@gmail.com ${ }^{3}$,cindywiriani97@gmail.com ${ }^{4}$ \\ DOI: http://dx.doi.org/10.31869/rtj.v4i2.2636
}

\begin{abstract}
Academic Information System (SIA) or Sistem Information Akademik (SIA) is an information system created to help the process of processing all school civitas data designed to assist the processing of all data of the school community. At SMA N 1 Palembayan, grades, school civitas biodata, and enrollment of new students still utilize simple applications from Dapodik and Ms. Office applications and archived in the form of paper that causes data to be vulnerable to damage, and lost. In addition, the entire community of schools and the general public is difficult and slow in obtaining school information if at any time needed due to the dissemination of information that is still manual. Therefore, to facilitate schools in the effective and efficient processing and dissemination of information, a web-based academic information system is needed. This academic information system was developed using PHP programming language with MySql storage media and supported by other programs. The final result of this research is the creation of a web-based academic information system that can present academic and non-academic information to schools easily and quickly for both the school community and the general public.
\end{abstract}

\section{Keywords : Academic Information System, SMA N 1 Palembayan, WEB, PHP, MySql}

Abstrak: Sistem Informasi Akademik (SIA) merupakan sistem informasi yang dibuat untuk membantu proses pengolahan seluruh data civitas sekolah. Pada SMA N 1 Palembayan proses pengolahan data berupa absensi, nilai, biodata civitas sekolah, dan pendaftaran siswa baru masih memanfaatkan aplikasi sederhana dari aplikasi Dapodik dan Ms. Office dan yang diarsip berupa kertas sehingga menyebabkan data rentan rusak, dan hilang. Selain itu seluruh civitas sekolah dan masyarakat umum sulit dan lambat dalam memperoleh informasi sekolah jika sewaktu-waktu dibutuhkan karena penyebaran informasi yang masih manual. Oleh karena itu untuk mempermudah sekolah dalam pengolahan dan penyebaran informasi secara efektif dan efisien dibutuhkanlah sebuah sistem informasi akademik berbasis web. Sistem informasi akademik ini dikembangkan dengan menggunakan bahasa pemograman PHP dengan media penyimpanan MySql dan didukung program lainnya. Hasil akhir dari penelitian ini adalah terciptanya sistem informasi akademik berbasis web yang dapat menyajikan informasi akademik dan non akademik sekolah secara mudah dan cepat baik untuk civitas sekolah maupun masyarakat umum.

\section{Kata Kunci : Sistem Informasi Akademik, SMA N 1 Palembayan, , WEB, PHP, MySql}

\section{PENDAHULUAN}

Teknologi menjadi sebuah kebutuhan bagi manusia dalam mengakses suatu informasi yang mudah dan cepat. Saat ini teknologi selalu berkembang dan mengalami perubahan dan telah muncul berbagai inovasi yang terus-menerus. Bidang sistem informasi ini telah berkembang ke berbagai bidang salah satunya dalam bidang pendidikan. Dalam bidang pendidikan, sistem informasi yang dapat diterapkan ialah sistem informasi akademik.
Sistem Informasi Akademik (SIA) merupakan sistem yang dibangun untuk mengelola data-data berupa data akademik, data sekolah, data siswa dan data guru, sehingga memberikan kemudahan kepada pengguna dalam administrasi sekolah secara terkomputerisasi. Sistem Informasi Akademik (SIA) juga merupakan sistem informasi yang dibuat untuk membantu proses kerja yang ada pada sekolah. Adapun fitur yang ada di SIA sendiri seperti fitur yang dapat mempermudah proses absensi, proses pengaturan jadwal pelajaran dan ujian, proses penilaian siswa, 
proses promosi sekolah, serta proses lainnya tergantung pada kebutuhan sekolah.

Berdasarkan studi sebelumnya dengan adanya sistem informasi akademik berbasis web di sekolah bertujuan untuk mempermudah pihak sekolah dalam proses kegiatan belajar mengajar. Dengan adanya Sistem informasi berbasis online diharapkan dapat meningkatkan efektifitas dan efisiensi proses kegiatan belajar mengajar. Sistem informasi akademik berbasis online yang dibangun dapat memenuhi kebutuhan pengguna (internal maupun exsternal) akan data dan informasi yang berkualitas (Yani dkk., 2019:260).

SMA N 1 Palembayan terletak di Kecamatan Palembayan, Kabupaten Agam ini merupakan SMA pertama yang ada di Kecamatan Palembayan dan sudah cukup lama berdiri. SMA ini belum memiliki website sendiri yang dapat mempermudah civitas sekolah dalam proses pengolahan data untuk menghasilkan informasi yang mudah dan cepat bagi civitas sekolah dan masyarakat luar. Pengolahan data di SMA N 1 Palembayan beberapa diantaranya masih dilakukan dengan cara konvensional, seperti data profil sekolah, absensi, data prestasi sekolah, data penjadwalan pelajaran dan jadwal mengajar masih diolah melalui buku dan pengetikan di Ms.Office, yang memungkinkan terjadinya duplikat data karena pemeriksaan penulisannya harus dilakukan dengan mengecek dari awal. Sedangkan untuk data civitas sekolah seperti data guru, data siswa berupa data nilai sudah diolah menggunakan sistem dan aplikasi yang diberikan oleh Kemendikbud yaitu dapodik, namun sistem yang diberikan ini sederhana dan terbatas, karena data yang tersimpan di dalamnya tidak sampai lima tahun terakhir, jadi beberapa data masih ada yang disimpan dalam Ms.Office baik itu Ms. Word ataupun Ms. excel dan yang dapat mengakses hanya sebatas bagian administrasi sekolah saja. Media penyimpanan data di SMA N 1 Palembayan sendiri beberapa data masih berupa arsip menggunakan map dan disimpan dalam lemari serta beberapa data lainnya disimpan di Ms.Office, sehingga untuk pencarian data kembali saat dibutuhkan oleh civitas sekolah membutuhkan waktu yang lama dan ini tidak efektif dan efisien.

Selain itu untuk memperoleh informasi sekolah, baik siswa, guru maupun masyarakat umum harus bertanya langsung kepada pihak sekolah untuk memperoleh informasi terbaru dan yang mereka perlukan, hal ini tentu membutuhkan waktu yang lama dan memungkinkan terjadinya perbedaan maksud bagi yang menerima informasi. Hal ini dikarenakan tidak adanya sistem khusus yang bisa mempermudah proses penyebaran informasi sekolah kepada yang membutuhkan.

Untuk mengatasi permasalahan di SMA N 1 Palembayan adalah dengan membuat sistem informasi akademik berbasis web yang dapat di akses user yang terdiri dari siswa, guru, staf TU, calon siswa, orang tua siswa, dan kepala sekolah yang memiliki akun login ke sistem dengan mudah dan cepat asalkan terkoneksi dengan jaringan internet.

\section{METODOLOGI PENELITIAN}

Proses penelitian ini akan dijelaskan mengenai teknik pengumpulan data, analisis data, pendekatan yang digunakan dan metode pengembangan sistem.

1. Teknik pengumpulan data yang digunakan dalam penelitian ini yaitu:

a. Observasi

Observasi atau pengumpulan data dilakukan dengan cara pengamatan langsung di SMA N 1 Palembayan dengan mengamati bagaimana sistem akademik yang sedang berlangsung di sekolah.

b. Wawancara

Wawancara dilakukan kepada pihak SMA N 1 Palembayan mulai dari kepala sekolah, guru, staf tata usaha, dan siswa yang menjadi subjek dalam penelitian ini untuk mengetahui sistem informasi akademik seperti apa yang akan dirancang dalam penelitian ini.

c. Kuesioner

Dengan membuat daftar pertanyaan dan menyebarkannya kepada siswa, guru dan staf tata usaha yang ada di SMA N 1 Palembayan untuk dapat dijawab, sehingga dihasilkan penilaian dan kesimpulan untuk dapat ditindak lanjuti.

d. Studi Pustaka

Studi pustaka dilakukan dengan mengumpulkan data dan informasi sebagai bahan pedoman atau referensi yang lebih mendalam terkait topik yang dibahas dalam penelitian ini khususnya analisis dan perancangan sistem informasi akademik. 
Referensi ini bisa didapatkan dari bukku-buku, jurnal, karya ilmiah, e-book dan sumber lainnya yang dapat dipercaya.

Hasil dari pengumpulan data melalui empat tahap ini selanjutnya akan dianalisis. Analisis data ini dimulai dengan mempelajari seluruh data yang sudah diperoleh baik dari hasil wawancara, pengamatan langsung di lapangan berupa dokumen pribadi, dokumen resmi sekolah, foto, penyebaran kuesioner maupun melalui studi pustaka sebelumnya.

\section{Model Pendekatan Penelitian}

Model pendekatan penelitian ini mencakup metode yang digunakan dalam pembuatan sistem informasi akademik di SMA N 1 Palembayan.

a. Model Pengembangan Perangkat Lunak

Metode yang digunakan pada penelitian ini adalah metode SDLC (Software Development Life Cycle) air terjun (waterfall) yang mempunyai tahapan-tahapan seperti analisis kebutuhan perangkat lunak, desain, pembuatan kode program, pengujian, pendukung (support) dan pemeliharaan (main-tenance) dan alat bantu perancangan sistem menggunakan UML. Adapun tahapan-tahapan metode waterfall menurut (Salahuddin, 2016: 29) sebagai berikut:

1) Analisis Kebutuhan Perangkat Lunak

Proses pengumpulan kebutuhan dilakukan secara intensif untuk menspesifikasi-kan kebutuhan perangkat lunak seperti apa yang dibutuhkan oleh user. Spesifikasi kebutuhan perangkat lunak pada tahap ini perlu untuk didokumentasikan.

2) Desain

Desain perangkat lunak adalah proses multi langkah yang fokus pada desain pembuatan program perangkat lunak termasuk struktur data, arsitektur perangkat lunak, representasi antar-muka, dan prosedur pengodean. Tahap ini mentranslasi kebutuhan perangkat lunak dari tahap analisis kebutuhan representasi desain agar dapat diimplementasikan menjadi program pada tahap selanjutnya. Desain perangkat lunak yang dihasilkan pada tahap ini juga perlu didokumentasikan.

3) Pembuatan Kode Program

Desain harus ditranslasikan ke dalam program perangkat lunak. Hasil dari tahapan ini adalah program komputer sesuai dengan desain yang telah dibuat pada tahap desain.

4) Pengujian

Pengujian fokus pada perangkat lunak secara dari segi logik dan fungsional dan memastikan bahwa semua bagian sudah diuji. Hal ini dilakukan untuk meminimalisir kesalahan (error) dan memastikan keluaran yang dihasilkan sesuai dengan yang diinginkan.

5) Pendukung (support) atau pemeliharaan (maintenance)

Tidak menutup kemungkinan sebuah perangkat lunak mengalami perubahan ketika sudah dikirimkan ke user. Perubahan bisa terjadi karena adanya kesalahan yang muncul dan tidak terdeteksi saat pengujian atau perangkat lunak harus beradaptasi dengan lingkungan baru. Tahap pendukung atau pemeliharaan dapat mengulangi proses pengembangan mulai dari analisis spesifikasi untuk perubahan perangkat lunak yang sudah ada, tapi tidak untuk membuat perangkat lunak baru. Ilustrasi model SDLC air terjun (waterfall) dapat dilihat pada Gambar 1.

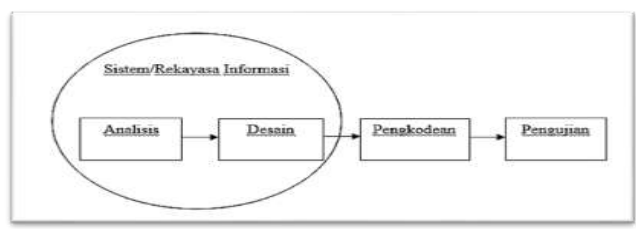

Gambar 1. Model Pengembangan Perangkat Lunak

Sumber: (Salahuddin, 2016:28-30)

\section{b. Pengujian dan Evaluasi Sistem}

Pada tahap ini dilakukan pengujian terhadap sistem yang telah dibuat. Pengujian ini nantinya menggunakan pengujian black-box, 
dimana pengujiannya berfokus pada persyaratan fungsional dari perangkat lunak. Setelah dilakukan pengujian selanjutnya dimintai tanggapan dari user untuk penilaian dan evaluasi dari sistem yang dibangun ini.

\section{HASIL DAN PEMBAHASAN}

Sistem informasi akademik ini dapat mempermudah civitas sekolah dalam pengolahan data akdemik menjadi sebuah informasi yang berguna. Dengan adanya sistem informasi akademik berbasis website, civitas sekolah tidak perlu lagi menyimpan file dalam bentuk tumpukan map dengan pengetikan menggunakan Ms.Office. Melalui sistem informasi akademik ini civitas sekolah dapat mengakses informasi dimanapun asal memiliki akun login dan tersambung dengan jaringan internet.

Hasil dari pengolahan data memberi gambaran secara umum kepada user tentang sistem yang baru. Rancangan sistem mengidentifikasikan komponen-komponen sistem informasi yang didesain secara rinci. Desain global sistem ini mengacu pada desain umum aplikasi dengan struktur yang berurutan. use case diagram menjelaskan manfaat dari aplikasi ini jika dilihat dari sudut pandang orang yang berada di luar sistem. Diagram ini menunjukkan fungsionalitas suatu sistem dan bagaimana sistem berinteraksi dengan dunia luar. Bentuk dari use case diagram yang diusulkan dapat dilihat pada Gambar 2.

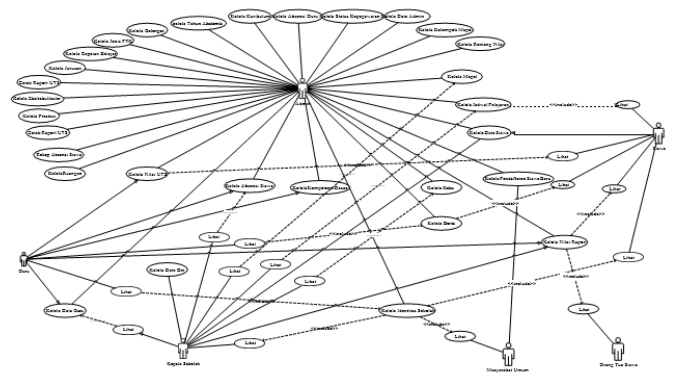

Gambar 2. Use Case diagram Sistem Informasi Akademik

Adapun hasil dari sistem informasi akademik pada SMA N 1 Palembayan berbasis website menggunakan framework bootsrap yaitu dapat memudahkan civitas sekolah dalam pembuatan, penyimpanan,pengeditan,penghapusan, dan pelaporan informasi yang lebih efektif dan efisien. Uraian hasil penelitian ini dapat dilihat sebagai berikut:

\section{Menu Utama}

a. Halaman Utama Website

Halaman utama website merupakan tampilan utama dari sistem informasi akdemik SMA N 1 Palembayan. Halaman Utama Website dapat dilihat pada Gambar 3.

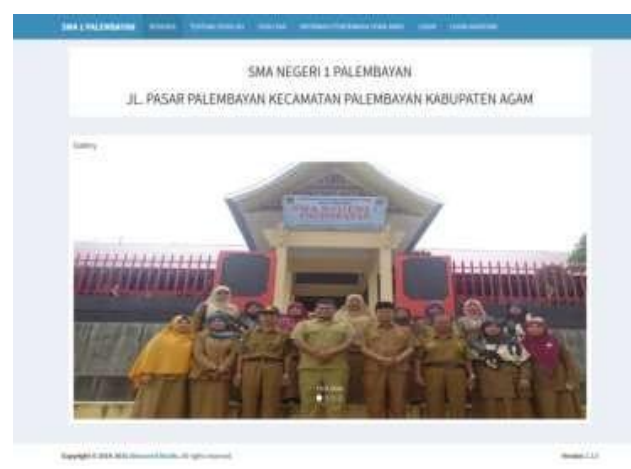

Gambar 3. Halaman Utama Website

b. Halaman Tentang Sekolah

Merupakan halaman yang berisikan informasi mengenai sekolah, seperti sejarah sekolah, dan visi misi sekolah. Halaman Tentang Sekolah dapat dilihat pada Gambar 4.

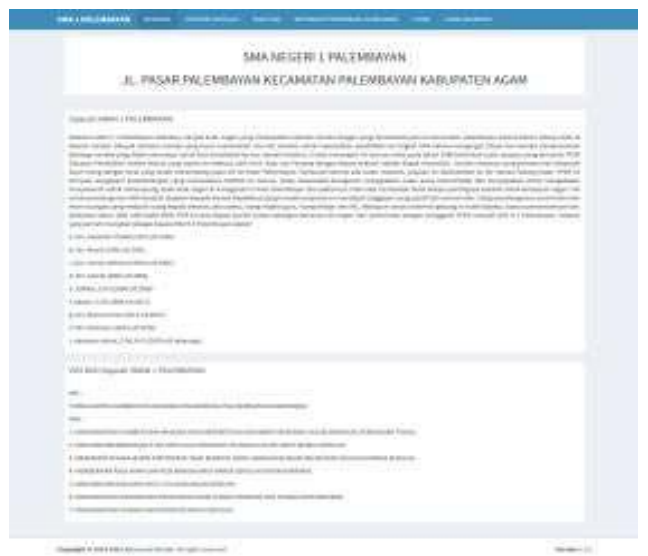

Gambar 4. Halaman Tentang Sekolah

c. Menu Fasilitas Sekolah

Merupakan menu yang dapat dipergunakan semua user dan masyarakat umum untuk melihat fasilitas apa saja yang ada di sekolah. Menu fasilitas sekolah dapat dilihat pada Gambar 5. 


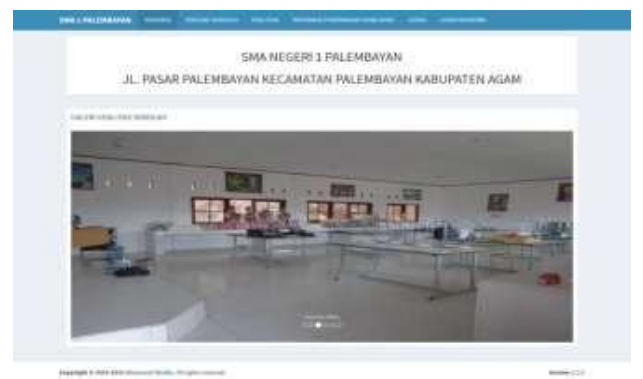

Gambar 5. Menu Fasilitas Sekolah

\section{d. Menu Informasi Pendaftaran Siswa} Baru

Merupakan menu yang dapat dipergunakan oleh calon peserta didik baru untuk memperoleh pin agar dapat mengisi formulir pendaftaran siswa baru secara online. Menu informasi pendaftaran siswa baru dapat dilihat pada Gambar 6.

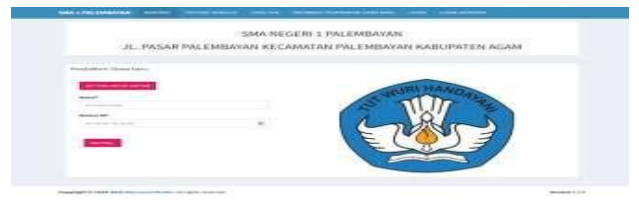

Gambar 6. Menu Informasi Pendaftaran Siswa Baru

e. Menu Login Pendaftaran Siswa Baru

Merupakan form login yang dapat dipergunakan oleh calon peserta didik baru untuk mengisi formulir pendaftaran setelah didapatkannya kode aktivasi untuk login pada halaman informasi pendaftaran siswa baru. Menu login pendaftaran siswa baru dapat dilihat pada Gambar 7.

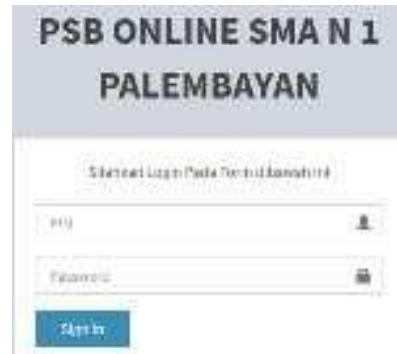

Gambar 7. Menu Login Pendaftaran Siswa Baru

\section{f. Menu Login Civitas Sekolah}

Merupakan form untuk dapat masuk ke dalam website bagi user yang memiliki hak akses, yaitu guru, admin, kepala sekolah dan siswa. Menu login civitas sekolah dapat dilihat pada Gambar 8.

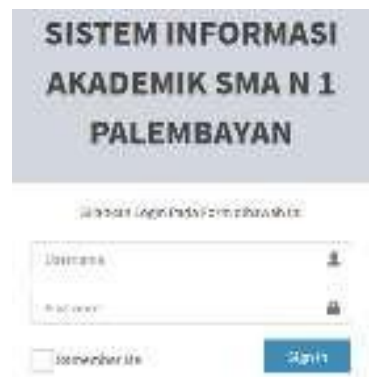

Gambar 8. Menu Login Civitas Sekolah

2. Menu Input

Menu entry data merupakan menu untuk memasukkan data-data terkait dengan akademik SMA N 1 Palembayan yang terdiri dari data master yang berguna memasukkan data identitas sekolah, data kurikulum, data tahun akademik, data ruangan, data golongan, data jenis PTK, data jurusan, data kelas, data status kepegawaian. Kemudian ada data pengguna yang terdiri dari data administrator, data guru, dan data siswa. Selanjutnya ada data akademik yang terdiri dari data kelompok mata pelajaran, data mata pelajaran, data jadwal pelajaran, data kompetensi dasar, dan data rentang nilai. Kemudian ada data pengumuman yang berguna memasukkan pengumuman harian yang ada di sekolah. Adapun bentuk form dari masing-masing menu input dapat dilihat pada Gambar 9.

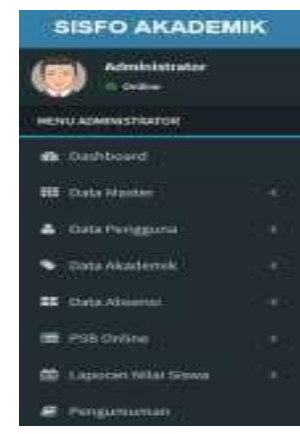

Gambar 9. Menu Entry Data Pada Halaman Admin

a .Form Input Data Identitas Sekolah

Form input data identitas sekolah merupakan form yang digunakan untuk memasukkan data identitas sekolah dan menyimpannya dalam sebuah database, dimana ada beberapa atribut yang harus diisi yaitu, nama sekolah, npsn, nss, 
alamat sekolah, kode pos, no telepon, kelurahan, kecamatan, kabupaten/ kota, provinsi, website dan email sekolah. Form ini dapat diisi oleh admin. Bentuk form input identitas sekolah dapat dilihat pada Gambar 10.

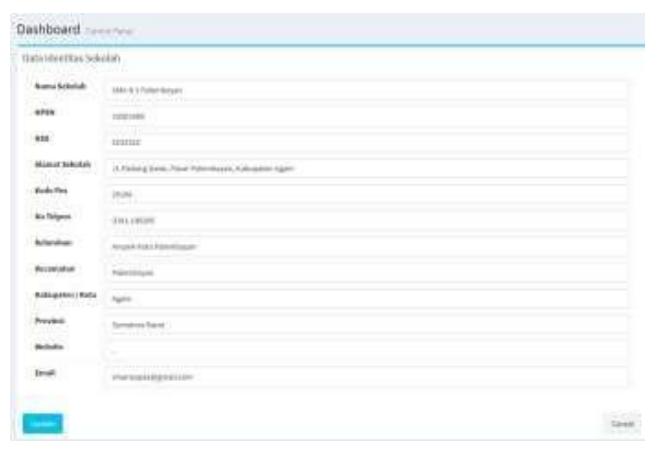

Gambar 10. Form Input Identitas Sekolah

b. Form Input Data Kurikulum Sekolah

Form input data kurikulum sekolah merupakan form yang digunakan untuk memasukkan data kurikulum sekolah dan menyimpannya dalam sebuah database, dimana ada beberapa atribut yang harus diisi seperti nama kurikulum dan status aktif. Form ini dapat diisi oleh admin saja. Bentuk form input data kurikulum sekolah dapat dilihat pada Gambar 11.

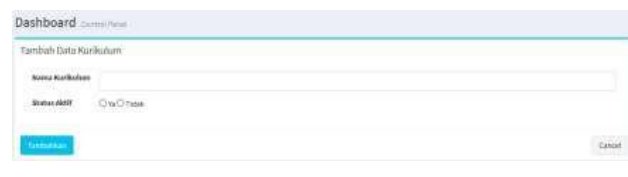

Gambar 11. Form Input Data

Kurikulum Sekolah

c. Form Input Data Tahun Akademik Sekolah

Form input data tahun akademik sekolah adalah form yang terdiri dari beberapa atribut yang harus diisi seperti kode tahun, nama tahun, keterangan dan status aktif. Form ini dapat diisi oleh admin. Bentuk form input data tahun akademik sekolah dapat dilihat pada Gambar 12.

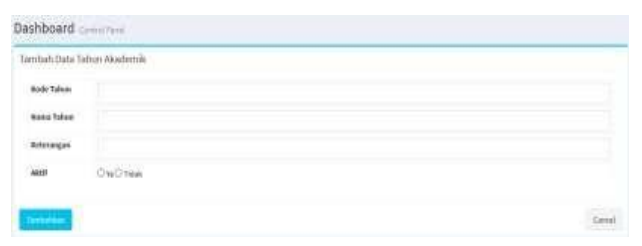

Gambar 12. Form Input Tahun Akademik Sekolah

e. Form Input Data Golongan

Form input data golongan merupakan form terdiri dari beberapa atribut yang harus diisi yaitu, nama golongan dan keterangan. Form ini dapat diisi oleh admin. Bentuk form input data golongan dapat dilihat pada Gambar 13.

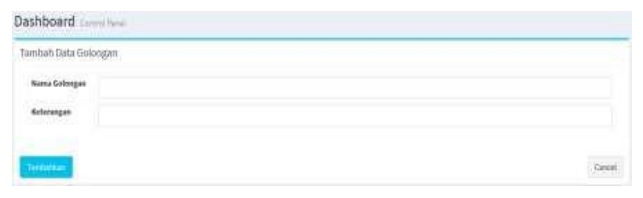

Gambar 13. Form Input Data Golongan

\section{j. Form Input Data Siswa}

Form input data siswa merupakan form input yang terdiri dari beberapa atribut yang harus diisi yaitu, NIPD, NISN, Password, nama siswa, kelas, angkatan, jurusan, alamat siswa, dusun, kelurahan, kecamatan, kode pos, status awal, foto, nik, tempat lahir, tanggal lahir, jenis kelamin, agama, kebutuhan khusus, jenis tinggal, transportasi, nomor handphone, alamat email, SKHUN, penerima KPS, nomor KPS, status siwa, serta data orang tua siswa. Form ini dapat diisi oleh admin dan siswa yang telah terdaftar di sekolah. Bentuk form input data siswa dapat dilihat pada Gambar 14. 


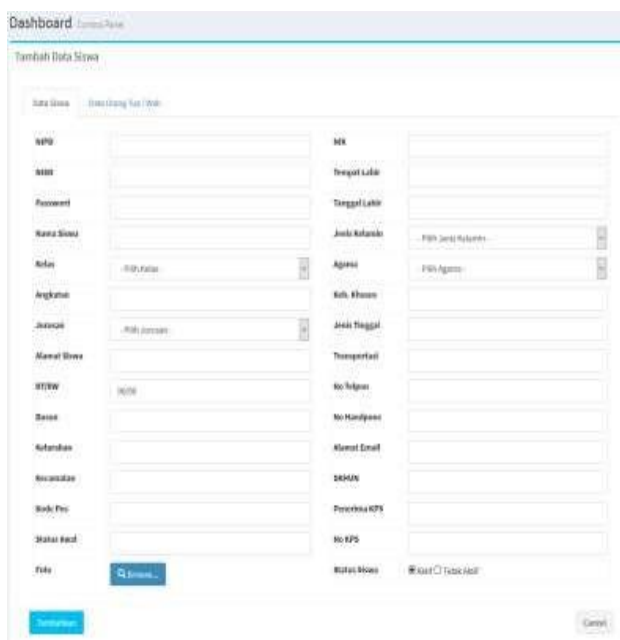

Gambar 14. Form Input Data Siswa

\section{k. Form Input Data Guru}

Form input merupakan form input yang terdiri dari beberapa atribut yang harus diisi yaitu, NIP, password, nama lengkap, tempat lahir, tanggal lahir, jenis kelamin, agama, nomor hp, alamat email, alamat, dusun, kelurahan, kecamatan, kode pos, NUPTK, bidang studi, jenis PTK, tugas tambahan, status pegawai, status keaktifan, status nikah, foto, NIK, SK CPNS, tanggal CPNS, SK pengangkatan, tahun pengangkatan, lembaga pengangkatan, golongan, sumber gaji, ahli laboratorium, nama ibu kandung, nama suami/ istri, tahun PNS, lisensi kepsek, jumlah sekolah binaan, kewarganegaraan, NPWP. Form ini dapat diisi oleh admin dan guru sekolah. Bentuk form input data guru dapat dilihat pada Gambar 15

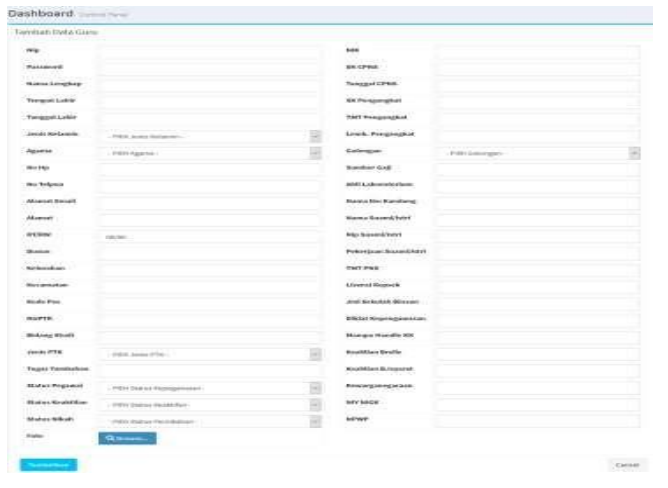

Gambar 15. Form Input Data Guru m. Form Input Data Kelompok Mata Pelajaran

Form input data kelompok mata pelajaran merupakan form input yang terdiri dari beberapa atribut yang harus diisi seperti jenis dan nama kelompok mata pelajaran. Form ini dapat diisi oleh admin. Bentuk form input data kelompok mata pelajaran dapat dilihat pada Gambar 16.

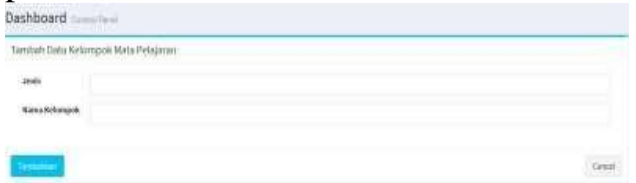

Gambar 16. Form Input Data Kelompok Mata Pelajaran

\section{q. Form Input Data Rentang Nilai}

Form input data rentang nilai merupakan form input nilai yang terdiri dari beberapa atribut yang harus diisi yaitu, kelas, dari, sampai, grade, dan keterangan. Form ini dapat diisi oleh admin. Bentuk form input data rentang nilai dapat dilihat pada Gambar 17.

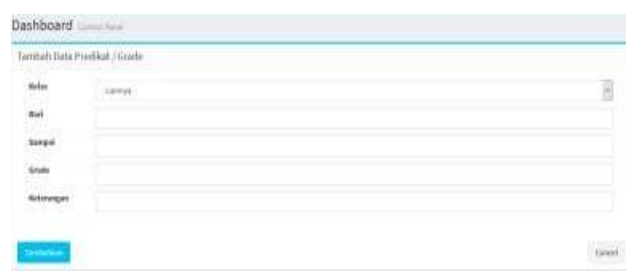

Gambar 17. Form Input Rentang Nilai

4. Laporan

a.Laporan Data Siswa

Berfungsi untuk menampilkan seluruh data siswa SMA N 1 Palembayan tergantung kelas yang dipilih. Hasil pada laporan ini terdiri dari data NIPD, NISN, nama siswa, jenis kelamin, dan jurusan. Bentuk laporan data siswa dapat dilihat pada Gambar 18

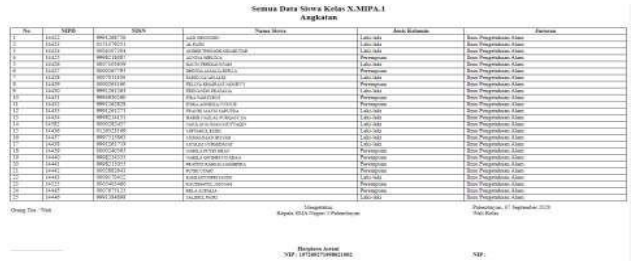

Gambar 18. Laporan Data Siswa 
b. Laporan Nilai Siswa

Berfungsi untuk menampilkan hasil atau nilai yang diperoleh siswa selama satu semester proses pembelajaran. Isi dari laporan ini terdiri dari mata pelajaran, kelompok mata pelajaran, KKM, nilai pengetahuan dan predikat, nilai keterampilan dan predikat. Bentuk laporan data nilai siswa dapat dilihat pada Gambar 19.

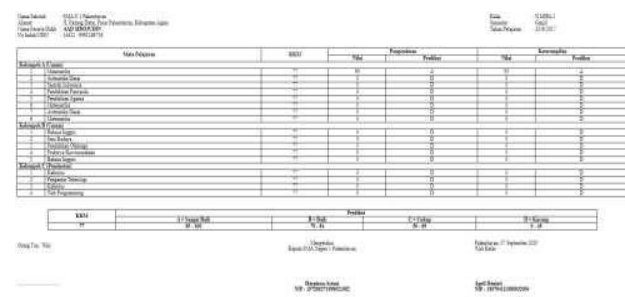

Gambar 19. Laporan Nilai Siswa

d. Laporan Formulir Pendaftaran Siswa Baru

Berfungsi untuk menampilkan data siswa yang telah melakukan pendaftaran di SMA N 1 Palembayan melalui pendaftaran online. Isi dari laporan data siswa ini terdiri dari nama siswa, tempat tanggal lahir, jenis kelamin, agama, alamat, telepon, serta data orang tua. Bentuk laporan formulir pendaftaran dapat dilihat pada Gambar 20.

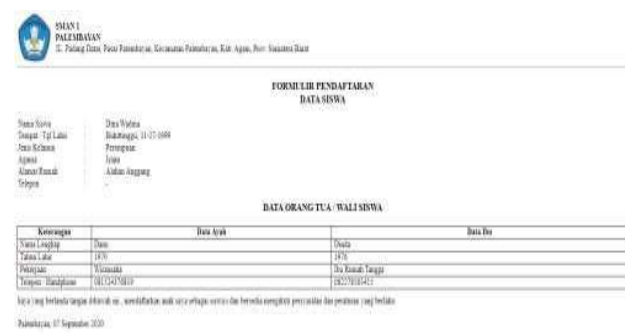

Gambar 20. Laporan Formulir Pendaftaran Siswa Baru

Pengujian yang dilakukan terhadap fungsi sistem informasi akademik berbasis web pada SMA N 1 Palembayan dapat dilihat pada Tabel 1 .

Tabel 1. Modul Pengujian

\begin{tabular}{|c|c|c|c|}
\hline \multicolumn{2}{|c|}{ Deskripsi Sistem } & $\begin{array}{c}\text { Prosedu } \\
\text { r } \\
\text { Pengujia } \\
\text { n }\end{array}$ & $\begin{array}{c}\text { Hasil } \\
\text { Penguji } \\
\text { an } \\
\text { Sistem }\end{array}$ \\
\hline $\begin{array}{l}\text { Sebel } \\
\text { um }\end{array}$ & $\begin{array}{l}\text { Sesud } \\
\text { ah }\end{array}$ & & \\
Penel & $\begin{array}{l}\text { Ditera } \\
\text { itian }\end{array}$ & & \\
pkan & & \\
\hline
\end{tabular}

\begin{tabular}{|c|c|c|c|}
\hline & $\begin{array}{l}\text { Sistem } \\
\text { Yang } \\
\text { Diusulk } \\
\text { an }\end{array}$ & & \\
\hline $\begin{array}{l}\text { Tida } \\
\mathrm{k} \\
\text { ada } \\
\text { hala } \\
\text { man } \\
\text { bera } \\
\text { nda } \\
\text { pada } \\
\text { web } \\
\text { seko } \\
\text { lah } \\
\text { yan } \\
\text { g } \\
\text { me } \\
\text { mua } \\
\mathrm{t} \\
\text { tent } \\
\text { ang } \\
\text { seko } \\
\text { lah, } \\
\text { fasil } \\
\text { itas, } \\
\text { info } \\
\text { rma } \\
\text { si } \\
\text { pene } \\
\text { rima } \\
\text { an } \\
\text { sisw } \\
\text { a } \\
\text { baru, } \\
\text { login } \\
\text { pend } \\
\text { aftara } \\
\mathrm{n} \\
\text { siswa } \\
\text { baru, } \\
\text { dan } \\
\text { login } \\
\text { akade } \\
\text { mik. }\end{array}$ & $\begin{array}{l}\text { Ada } \\
\text { halam } \\
\text { an } \\
\text { berand } \\
\text { a pada } \\
\text { websit } \\
\text { e yang } \\
\text { memu } \\
\text { at } \\
\text { tentan } \\
\text { g } \\
\text { sekola } \\
\text { h, } \\
\text { fasilita } \\
\text { s, } \\
\text { inform } \\
\text { asi } \\
\text { peneri } \\
\text { maan } \\
\text { siswa } \\
\text { baru, } \\
\text { login } \\
\text { pendaf } \\
\text { taran } \\
\text { siswa } \\
\text { baru, } \\
\text { dan } \\
\text { login } \\
\text { akade } \\
\text { mik }\end{array}$ & $\begin{array}{l}\text { Menampi } \\
\text { l-kan } \\
\text { halaman } \\
\text { web dan } \\
\text { mengope } \\
\text { rasikan } \\
\text { setiap } \\
\text { menunya }\end{array}$ & $\begin{array}{l}\text { Semua } \\
\text { menu } \\
\text { dapat } \\
\text { ditamp } \\
\text { ilkan } \\
\text { dengan } \\
\text { baik }\end{array}$ \\
\hline $\begin{array}{l}\text { Tidak } \\
\text { dapat } \\
\text { mela } \\
\text { kuka } \\
\mathrm{n} \\
\text { pend } \\
\text { aftara } \\
\mathrm{n} \\
\text { siswa }\end{array}$ & $\begin{array}{l}\text { Sudah } \\
\text { bisa } \\
\text { melak } \\
\text { ukan } \\
\text { pendaf } \\
\text { taran } \\
\text { siswa } \\
\text { baru } \\
\text { secara }\end{array}$ & $\begin{array}{l}\text { Melakuk } \\
\text { an } \\
\text { pendaftar } \\
\text { an siswa } \\
\text { baru }\end{array}$ & $\begin{array}{l}\text { Menu } \\
\text { pendaft } \\
\text { aran } \\
\text { siswa } \\
\text { baru } \\
\text { dapat } \\
\text { berope } \\
\text { rasi } \\
\text { dengan }\end{array}$ \\
\hline
\end{tabular}


Vol. 4 No.2 Juni 2021

Rang Teknik Journal

http://jurnal.umsb.ac.id/index.php/RANGTEKNIKJOURNAL

\begin{tabular}{|c|c|c|c|}
\hline $\begin{array}{l}\text { baru } \\
\text { secar } \\
\text { a } \\
\text { onlin } \\
e\end{array}$ & $\begin{array}{l}\text { online } \\
\text { melalu } \\
\text { i web }\end{array}$ & & baik \\
\hline $\begin{array}{l}\text { Civi } \\
\text { tas } \\
\text { seko } \\
\text { lah } \\
\text { tida } \\
\mathrm{k} \\
\text { dapa } \\
\mathrm{t} \\
\text { logi } \\
n \mathrm{ke} \\
\text { hala } \\
\text { man } \\
\text { web } \\
\text { seko } \\
\text { lah }\end{array}$ & $\begin{array}{l}\text { Civita } \\
\mathrm{s} \\
\text { sekola } \\
\mathrm{h} \\
\text { dapat } \\
\text { login } \\
\text { mengg } \\
\text { unaka } \\
\mathrm{n} \\
\text { userna } \\
\text { me }\end{array}$ & $\begin{array}{l}\text { Melakuk } \\
\text { an login }\end{array}$ & $\begin{array}{l}\text { Login } \\
\text { berhasi } \\
1\end{array}$ \\
\hline $\begin{array}{l}\text { Tida } \\
\mathrm{k} \\
\text { ada } \\
\text { hala } \\
\text { man } \\
\text { adm } \\
\text { in } \\
\text { untu } \\
\mathrm{k} \\
\text { men } \\
\text { gelo } \\
\text { la } \\
\text { data } \\
\text { civit } \\
\text { as } \\
\text { seko } \\
\text { lah }\end{array}$ & $\begin{array}{l}\text { Sudah } \\
\text { ada } \\
\text { halam } \\
\text { an } \\
\text { admin } \\
\text { untuk } \\
\text { mengo } \\
\text { lah } \\
\text { data } \\
\text { civitas } \\
\text { sekola } \\
\text { h }\end{array}$ & $\begin{array}{l}\text { Menampi } \\
\text { lkan } \\
\text { halaman } \\
\text { admin } \\
\text { pada web }\end{array}$ & $\begin{array}{l}\text { Halam } \\
\text { an } \\
\text { admin } \\
\text { dapat } \\
\text { ditamp } \\
\text { ilkan } \\
\text { dengan } \\
\text { baik }\end{array}$ \\
\hline $\begin{array}{l}\text { Tidak } \\
\text { dapat } \\
\text { mena } \\
\text { mbah } \\
\text { meng } \\
\text { edit } \\
\text { dan } \\
\text { meng } \\
\text { hapus } \\
\text { data } \\
\text { identi } \\
\text { tas } \\
\text { sekol } \\
\text { ah } \\
\text { ke } \\
\text { dala }\end{array}$ & $\begin{array}{l}\text { Data } \\
\text { identit } \\
\text { as } \\
\text { sekola } \\
\text { h } \\
\text { dapat } \\
\text { ditamb } \\
\text { ah, } \\
\text { diedit } \\
\text { dan } \\
\text { dihapu } \\
\text { s ke } \\
\text { dalam } \\
\text { web }\end{array}$ & $\begin{array}{l}\text { Melaku } \\
\text { kan } \\
\text { penamb } \\
\text { ahan, } \\
\text { pengedi } \\
\text { tan dan } \\
\text { penghap } \\
\text { usan } \\
\text { data } \\
\text { identitas } \\
\text { sekolah }\end{array}$ & $\begin{array}{l}\text { Data } \\
\text { identita } \\
\text { s } \\
\text { sekola } \\
\text { h dapat } \\
\text { ditamb } \\
\text { ah, } \\
\text { diedit } \\
\text { dan } \\
\text { dihapu } \\
\text { s }\end{array}$ \\
\hline
\end{tabular}

\begin{tabular}{|c|c|c|c|}
\hline $\begin{array}{l}\mathrm{m} \\
\text { web }\end{array}$ & & & \\
\hline $\begin{array}{l}\text { Tidak } \\
\text { dapat } \\
\text { mena } \\
\text { mbah } \\
\text { meng } \\
\text { edit } \\
\text { dan } \\
\text { meng } \\
\text { hapus } \\
\text { data } \\
\text { kurik } \\
\text { ulum } \\
\text { sekol } \\
\text { ah ke } \\
\text { dala } \\
\text { m } \\
\text { web }\end{array}$ & $\begin{array}{l}\text { Data } \\
\text { kuriku } \\
\text { lum } \\
\text { sekola } \\
\text { h } \\
\text { dapat } \\
\text { ditamb } \\
\text { ah, } \\
\text { diedit } \\
\text { dan } \\
\text { dihapu } \\
\text { s ke } \\
\text { dalam } \\
\text { web }\end{array}$ & $\begin{array}{l}\text { Melaku } \\
\text { kan } \\
\text { penamb } \\
\text { ahan, } \\
\text { pengedi } \\
\text { tan dan } \\
\text { penghap } \\
\text { usan } \\
\text { data } \\
\text { kurikulu } \\
\text { m } \\
\text { sekolah }\end{array}$ & $\begin{array}{l}\text { Data } \\
\text { kurikul } \\
\text { um } \\
\text { sekola } \\
\text { h dapat } \\
\text { ditamb } \\
\text { ah, } \\
\text { diedit } \\
\text { dan } \\
\text { dihapu } \\
\text { s }\end{array}$ \\
\hline $\begin{array}{l}\text { Tidak } \\
\text { dapat } \\
\text { mena } \\
\text { mbah } \\
\text { ' } \\
\text { meng } \\
\text { edit } \\
\text { dan } \\
\text { meng } \\
\text { hapus } \\
\text { data } \\
\text { tahun } \\
\text { akade } \\
\text { mik } \\
\text { sekol } \\
\text { ah ke } \\
\text { dala } \\
\text { m } \\
\text { web }\end{array}$ & $\begin{array}{l}\text { Data } \\
\text { tahun } \\
\text { akade } \\
\text { mik } \\
\text { sekola } \\
\text { h dapat } \\
\text { ditamb } \\
\text { ah, } \\
\text { diedit } \\
\text { dan } \\
\text { dihapu } \\
\text { s ke } \\
\text { dalam } \\
\text { web }\end{array}$ & $\begin{array}{l}\text { Melaku } \\
\text { kan } \\
\text { penamb } \\
\text { ahan, } \\
\text { pengedi } \\
\text { tan dan } \\
\text { penghap } \\
\text { usan } \\
\text { data } \\
\text { tahun } \\
\text { akademi } \\
\mathrm{k} \\
\text { sekolah }\end{array}$ & $\begin{array}{l}\text { Data } \\
\text { tahun } \\
\text { akade } \\
\text { mik } \\
\text { sekola } \\
\text { h dapat } \\
\text { ditamb } \\
\text { ah, } \\
\text { diedit } \\
\text { dan } \\
\text { dihapu } \\
\text { s }\end{array}$ \\
\hline $\begin{array}{l}\text { Tidak } \\
\text { dapat } \\
\text { mena } \\
\text { mbah } \\
\text { meng } \\
\text { edit } \\
\text { dan } \\
\text { meng } \\
\text { hapus } \\
\text { data } \\
\text { ruang } \\
\text { an } \\
\text { sekol } \\
\text { ah }\end{array}$ & $\begin{array}{l}\text { Data } \\
\text { ruanga } \\
\mathrm{n} \\
\text { sekola } \\
\mathrm{h} \\
\text { dapat } \\
\text { ditamb } \\
\text { ah, } \\
\text { diedit } \\
\text { dan } \\
\text { dihapu } \\
\text { s ke } \\
\text { dalam } \\
\text { web }\end{array}$ & $\begin{array}{l}\text { Melaku } \\
\text { kan } \\
\text { penamb } \\
\text { ahan, } \\
\text { pengedi } \\
\text { tan dan } \\
\text { penghap } \\
\text { usan } \\
\text { data } \\
\text { ruangan } \\
\text { sekolah }\end{array}$ & $\begin{array}{l}\text { Data } \\
\text { ruanga } \\
\mathrm{n} \\
\text { sekolah } \\
\text { dapat } \\
\text { ditamb } \\
\text { ah, } \\
\text { diedit } \\
\text { dan } \\
\text { dihapu } \\
\text { s }\end{array}$ \\
\hline
\end{tabular}




\begin{tabular}{|l|l|l|}
\hline ke & & \\
dala & & \\
m & & \\
web & & \\
\hline
\end{tabular}

\section{PENUTUP}

Berdasarkan hasil dan pembahasan yang telah dilakukan, maka dapat diambil kesimpulan mengenai sistem informasi akademik berbasis website pada SMA N 1 Palembayan menggunakan framework bootsrap sebagai berikut:

1. Dengan adanya sistem informasi akademik ini penyebaran informasi di sekolah dapat tersebar secara menyeluruh.

2. Data Civitas sekolah sudah diolah dan disimpan di dalam database, sehingga data tidak mudah terduplikat atau hilang.

3. Sistem yang dirancang dapat memberikan kemudahan bagi masyarakat umum dalam melakukan pendaftaran siswa baru karena dapat dilakukan secara online.

4. Sekolah jadi lebih dikenal masyarakat luas karena sudah memiliki website sendiri.

5. Pengolahan nilai dan absensi siswa sudah terkomputerisasi.

6. Orang tua siswa dapat mengetahui informasi khususnya nilai siswa melalui pemberitahuan melalui email.

\section{UCAPAN TERIMA KASIH}

Ucapan terima kasih kepada LPPM STMIK Indonesia Padang dan juga Civitas SMAN 1 Palembayan yang telah membantu terlaksananya penelitian ini.

\section{DAFTAR PUSTAKA}

Ahmar, A. S. (2019). Panduan Sistem Informasi Akademik Sekolah Berbasis Web. Yayasan Ahmar Cendekia Indonesia.

Anggraeni, E. Y., \& Irviani, R. (2017). Pengantar Sistem Informasi. Andi. https://books.google.co.id/

Burrahman, A. (2018). Membangun Sistem Informasi Akademik Berbasis Web Pada Pondok Pesantren Salafiyah AlBaqiyatussa" Diyyah Tembilahan. Sistemasi, 6(1), 33. https://doi.org/ 10.32520/stmsi.v6i1.26

Christian, A., Hesinto, S., \& Agustina, A. (2018). Rancang Bangun Website Sekolah Dengan Menggunakan Framework Bootstrap (Studi Kasus
SMP Negeri 6 Prabumulih). Jurnal Sisfokom (Sistem Informasi Dan Komputer), 7(1), 22. https://doi.org/ 10.32736/sisfokom.v7i1.278

Farell, G., Saputra, H. K., \& Novid, I. (2018). Rancang Bangun Sistem Informasi Pengarsipan Surat Menyurat (Studi Kasus Fakultas Teknik Unp). Jurnal Teknologi Informasi Dan Pendidikan (JTIP), 11(2), 56-62.

Fatansyah. (2015). Basis Data. Informatika Bandung.

Martin, J., \& Tanaamah, A. R. (2018). Perancangan Dan Implementasi Sistem Informasi Penjualan Berbasis Desktop Website Menggunakan Framework Bootstrap Dengan Metode Rapid Application Development, Studi Kasus Toko Peralatan Bayi „Eeng Baby Shop." Jurnal Teknologi Informasi Dan Ilmu Komputer, 5(1), 57. https://doi.org/10.25126 /jtiik.201851547

Muslihuddin, M., \& Oktafianto. (2016). Analisis Perancangan Sistem Informasi. CV Andi Offset.

Putra, A. S., Febriani, O. M., \& Bachry, B. (2018). Implementasi Genetic Fuzzy System Untuk Mengidentifikasi Hasil Curian Kendaraan Bermotor Di Polda Lampung. SIMADA (Jurnal Sistem Informasi \& Manajemen Basis Data), l(1), 21. https://doi.org/ 10.30873/simada.v1i1.1110

Raharjo, B. (2015). Belajar Otodidak MySQL. Informatika Bandung.

Raharjo, B. (2018). Modul Pemograman WEB (HTML, PHP, \& MySQL/MariaDB (4th ed.). Modula.

Ridlo, I. A. (2017). Panduan Pembuatan Flowchart.

Salahuddin, R. A. dan M. (2016). Rekayasa Perangkat Lunak Terstruktur dan Berorientasi Objek (4th ed.). Informatika Bandung.

Sidik, B. (2017). Pemograman Web dengan PHP7. Informatika Bandung.

Simanjuntak, N. J., Suryadi, S., \& Silaen, G. J. . (2017). Sistem Pengarsipan Surat Bagian Organisasi Dan Tatalaksana Pada Kantor Bupati Labuhanbatu Berbasis Web. Jurnal Ilmiah AMIK Labuhan Batu, 5(3), 26-36. 
Susanti, M. (2016). Perancangan Sistem Informasi Akademik Berbasis Web Pada Smk Pasar Minggu Jakarta. Informatika, 3(1), 91-99.

Swara, G. Y., \& Pebriadi, Y. (2016). Rekayasa Perangkat Lunak Pemesanan Tiket Bioskop Berbasis Web. Jurnal TEKNOIF, 4(2), 27-39. 